Previously, we found that inflammatory mediators modulated the number and binding affinity of glucocorticoid receptors (GR) in human bronchial epithelial cell lines. In this study we investigated whether smoking and chronic obstructive pulmonary disease (COPD), both characterized by airway inflammation with increased levels of inflammatory mediators, affect GR characteristics in cultured human bronchial epithelial cells (HBEC). A statistically significant difference $w$ as found between the dissociation constant $\left(K_{d}\right)$ values in HBEC from smoking $\left(K_{d}=0.98 \pm\right.$ $0.08 \mathrm{nM}, n=6)$ and nonsmoking controls $\left(\mathrm{K}_{\mathrm{d}}=0.76 \pm\right.$ $0.10 \mathrm{nM}, P=0.03 ; n=5$ ), but no significant difference was found between the mean number of binding sites. Our results are the first indication that cultured HBEC from smokers possess GR with a lower binding affinity. This may result from the in flammation found in the airways from smokers. Furthermore, these results provide further evidence that the bronchial epithelium may be an actual target for inhaled glucocorticoid therapy.

Key words: Glucocorticoid receptors, Human bronchial epithelial cells, Chronic obstructive pulmonary disease, Smoking

\section{Glucocorticoid receptor expression in human bronchial epithelial cells: effects of smoking and COPD}

\author{
M. M. Verheggen, ${ }^{1,2}$ P. W. C. Adriaansen-Soeting, ${ }^{1}$ \\ C. A. Berrevoets, ${ }^{3}$ P. Th. W. van Hal, ${ }^{1,2}$ \\ A. O. Brinkmann, ${ }^{3}$ H. C. Hoogsteden ${ }^{2}$ and \\ M. A. Versnel ${ }^{1, C A}$
}

Departments of ${ }^{1}$ Immunology; ${ }^{2}$ Pulmonary Medicine; and ${ }^{3}$ Endocrinology and Reproduction, Erasmus

University and University Hospital

Rotterdam-Dijkzigt, PO Box 1738, 3000 DR

Rotterdam, The Netherlands

${ }^{\mathrm{CA}}$ Corresponding Author
Tel: $(+31) 104088086$
Fax: (+31) 104367601
Email: versnel @immu.fgg.eur.nl

\section{Introduction}

The bronchial epithelium has long been regarded as a passive barrier to protect the underlying tissue. ${ }^{1}$ Now, bronchial epithelial cells are also known to play an active role in airway inflammation. They are able to produce various inflammatory mediators including cytokines and eicosanoids. ${ }^{2,3}$ Bronchial epithelial cells recovered from asthmatic patients show increased gene expression for GM-CSF, IL-6 and IL-8. ${ }^{3}$ Furthermore, increased expression of endothelin-1, TNF- $\alpha$, IL-1 $\beta$ and MCP-1 has been demonstrated. ${ }^{4,5}$

Glucocorticoids are widely used in the treatment of inflammatory pulmonary diseases, e.g. bronchial asthma and chronic obstructive pulmonary disease (COPD) ${ }^{6}$ Recent studies showed that glucocorticoids are able to inhibit the release of some bronchial epithelial cell-derived cytokines. ${ }^{3,7}$ These effects of glucocorticoids combined with the above-mentioned role of bronchial epithelial cells in airway inflammation, suggest that glucocorticoid therapy may suppress airway inflammation, at least partially, by modulating the function of bronchial epithelial cells. This hypothesis is supported by the observation that the greater part of inhaled glucocorticoids precipitate on the epithelium of the larger airways..$^{8}$ A prerequisite for steroid responsiveness is the presence of specific glucocorticoid receptors (GR).

In a recent study we identified and characterized specific GR in two SV40/adenovirus-transformed human bronchial epithelial cell lines, BEAS $2 \mathrm{~B}$ and BEAS S6. ${ }^{9}$ We also demonstrated that inflammatory mediators such as IL- $1 ß$ and LPS may modulate the number and the binding affinity of GR in BEAS $2 \mathrm{~B}$ cells. Similar results were found by other investigators in human $\mathrm{T}$ cells, other cell lines and murine macrophages. ${ }^{10-12}$ These results indicate that inflammatory processes may influence the response of the bronchial epithelium to glucocorticoid therapy via locally produced cytokines.

Here, as an extension of our findings in cell lines, we report on the identification and characterization of specific GR in cultured human bronchial epithelial cells (HBEC). From the above-mentioned in vitro findings concerning the effects of inflammatory mediators on GR, it may be expected that inflammation in vivo may also affect GR characteristics. Therefore, we also studied whether in cultured HBEC from smokers and COPD patients, in whom general inflammation has been described, ${ }^{13}$ the number or binding affinity of GR is altered. 
Table 1. Clinical characteristics of subject groups

\begin{tabular}{lccrr}
\hline Subjects & Number & $\begin{array}{c}\text { Age } \\
\text { (years) }\end{array}$ & $\begin{array}{c}\text { Smoking } \\
\text { (pack-years) }\end{array}$ & $\begin{array}{c}\text { FEV } \\
\text { (\% of } \\
\text { predicted) }\end{array}$ \\
\hline Nonsmoking controls & 5 & $71 \pm 2$ & 0 & $87 \pm 6$ \\
Smoking controls & 6 & $59 \pm 3$ & 25 & $90 \pm 4$ \\
Nonsmoking COPD patients & 3 & $60 \pm 1$ & $\geq 35$ & $68 \pm 6$ \\
Smoking COPD patients & 5 & $60 \pm 3$ \\
\hline
\end{tabular}

Data are shown as mean \pm SEM.

\section{Materials and Methods}

\section{Subjects}

A total of 19 subjects were entered into the study (Table 1). Of the subjects eight fulfilled ATS criteria for COPD. ${ }^{14}$ COPD patients were nonallergic with complaints of chronic cough and sputum production. Chronic cough means that coughing occurs on most days during at least three consecutive months in two consecutive years. One-second forced expiratory volume $\left(\mathrm{FEV}_{1}\right)$ was measured in all subjects before entry into the study. COPD patients suffered from major airway obstruction, that is, the $\mathrm{FEV}_{1}$ was $<75 \%$ of predicted. No reversibility of airway obstruction in these eight patients was obtained after inhalation of $0.5 \mathrm{mg}$ terbutaline. Controls $(n=11)$ were subjects who denied any symptoms of asthma or COPD, and had normal lung function parameters. The COPD and control group contained five and six smoking individuals, respectively. From the nonsmoking controls one individual stopped smoking 12 years ago. Smoking individuals were current smokers with a smoking history of at least 35 pack-years.

\section{Isolation and culture conditions of HBEC}

Bronchial tissue was obtained from patients undergoing surgery for lung cancer and used immediately for culture of HBEC by a cell culture method described previously. ${ }^{15}$ Briefly, bronchial tissue distant from the tumour was cut into pieces and incubated either overnight at $4^{\circ} \mathrm{C}$ or $1 \mathrm{~h}$ at $37^{\circ} \mathrm{C}$ in $0.1 \%$ protease XIV (Sigma, St Louis, MO). Subsequently, epithelial cells were gently scraped from the tissue samples, washed twice in culture medium and plated onto $35-\mathrm{mm}$ dishes at a density of $2.5 \times 10^{5}$ cells/dish. HBEC were cultured in a 1:1 mixture of Dulbecco's modified Eagle's medium and Ham's F12 (DMEM/F12)(GIBCO, Paisley, UK), with supplements as described previously. ${ }^{15}$ Cells were characterized as epithelial cells by immunofluorescence staining using a mouse monoclonal antibody directed against a number of human cytokeratins (CK-1; DAKOpatts, Glostrup, Denmark). At least $99 \%$ of the isolated cells stained positive for cytokeratin.
When dishes were confluent, HBEC were passaged to $75 \mathrm{~cm}^{2}$ flasks and used for experiments after confluence. Twenty-four hours before performing GR binding experiments the medium was replaced by a basal medium of DMEM/F12 (1:1) with penicillin G sodium and streptomycin sulphate, but without hydrocortisone or other supplements to prevent influence of endogenous steroids on the number and affinity of GR.

\section{Cell lines}

BEAS $2 \mathrm{~B}$ is a SV-40/adenovirus transformed human bronchial epithelial cell line, which was kindly provided by Dr J. Lechner (Inhalation Toxicology Research Institute, Albuquerque, NM). ${ }^{16}$ Cells were maintained in a complete keratinocyte growth medium (KGM) containing bovine pituitary extract, EGF, penicillin $G$ sodium and streptomycin sulphate (GIBCO).

The COS-1 cell line was used as a negative control for GR Western blot experiments. The COS-1 cell line, derived from the kidney of a male adult African green monkey (American Type Culture Collection, Rockville, MD) was cultured in DMEM with 5\% FCS.

\section{Preparation of cytosol}

Flasks containing approximately $10 \times 10^{6}$ cells were washed twice with cold phosphate buffered saline (PBS) and HBEC were scraped in $0.5 \mathrm{ml}$ of buffer A (40 mM Tris-HCI pH 7.4, $1 \mathrm{mM} \mathrm{EDTA,} \mathrm{10 \%} \mathrm{(v/v)}$ glycerol, $10 \mathrm{mM}$ dithiothreitol, $10 \mathrm{mM} \mathrm{Na} 2 \mathrm{MoO}_{4}$ ) supplemented with $0.6 \mathrm{mM}$ phenylmethylsulphonyl fluoride (PMSF), $0.5 \mathrm{mM}$ bacitracine and $0.5 \mathrm{mM}$ leupeptin. The cells were lysed by freezing/thawing three times and the homogenate was centrifuged for $10 \mathrm{~min}$ at $400000 \times \boldsymbol{g} .{ }^{17}$ The supernatant was collected and stored at $-80^{\circ} \mathrm{C}$. Protein concentrations were determined according to the method of Bradford $^{18}$ and ranged from 1 to $2 \mu \mathrm{g} / \mu \mathrm{l}$. Cytosol preparations were used for both Western blotting and binding assays. 


\section{Western blotting}

Samples $(20 \mu \mathrm{l}$ cytosol containing $1 \mu \mathrm{g} / \mu \mathrm{l}$ protein $)$ were mixed with $5 \mu$ of $5 \times$ sample buffer $(1 \times$ sample buffer $=50 \mathrm{mM}$ Tris-HCI pH 6.8, $10 \%(\mathrm{v} / \mathrm{v})$ glyce rol, 2\% (w/v) SDS, $10 \mathrm{mM}$ dithiothre itol, $0.001 \%$ $(\mathrm{w} / \mathrm{v})$ bromophenol blue), boiled for $2.5 \mathrm{~min}$ and separated on a 7\% SDS-PAGE gel. After electrophoresis the gels were blotted to nitrocellulose membrane in blotting buffer (16.5 mM Tris- $\mathrm{HCl}, \mathrm{pH} 8.3,150 \mathrm{mM}$ glycine and $20 \% \mathrm{v} / \mathrm{v}$ methanol). The membranes were blocked for $1 \mathrm{~h}$ at RT with $1 \%$ block solution (Boehringer, Mannheim, Germany) and incubated for $1 \mathrm{~h}$ at room temperature with a commercially available GR polyclonal rabbit antibody, no. 57 (PA1-511; Affinity Bioreagents, Neshanic Station, NJ), diluted $1: 250$ in $0.5 \%$ block solution. Membranes were washed tw ice with PBS/T ween $0.1 \%$ and tw ice w ith $0.5 \%$ block solution, then incubated with horseradish peroxidase-conjugated goat anti-rabbit-IgG (Sigma) for $1 \mathrm{~h}$ at RT. After $4 \times 15 \mathrm{~min}$ washes (PBS/Tween $0.1 \%$ ) proteins were detected with Boehringer-Mannheim's Chemiluminescence Western Blotting kit and membranes were exposed to X-ray film.

\section{Steroids}

${ }^{3}$ H-labelled dexamethasone $\left(1,2,4,6,7 \quad\left[{ }^{3} \mathrm{H}\right]\right.$ dexamethasone; specific activity $81 \mathrm{Ci} / \mathrm{mmol}$ ) was obtained from Amersham (Buckinghamshire, UK). Nonradioactive dexamethasone was kept in a stock solution of 2 $\times 10^{-3} \mathrm{M}$ in ethanol (Duchefa bv. Haarlem, the Netherlands).

\section{Binding assays}

GR numbers and $K_{d}$ values were determined according to established methods. ${ }^{19}$ Six serial doubling dilutions $(50 \mu \mathrm{l})$ were prepared in duplicate in PBS to final ${ }^{3} \mathrm{H}$-labelled dexamethasone concentrations of 32 , $16,8,4,2$, and $1 \mathrm{nmol} / 1$, respectively. For measurements of nonspecific binding, parallel dilutions of ${ }^{3}$ H-labelled dexamethasone plus a 100 -fold molar excess of nonradioactive dexamethasone were prepared. To each of the 24 tubes $150 \mu \mathrm{l}$ of the cytosol preparation was added and the mixture was incubated overnight at $4^{\circ} \mathrm{C}$. Binding equilibrium was reached at all concentrations after incubation overnight at $4^{\circ} \mathrm{C}$. Subsequently, $160 \mu \mathrm{l}$ aliquots of each incubation mixture were transferred to albumin $(0.1 \%)$ coated tubes, $750 \mu \mathrm{l}$ of protamine dihydrochloride solution $(0.5 \mathrm{mg} / \mathrm{ml})$ was added and tubes were centrifuged for $15 \mathrm{~min}$ at $4000 \mathrm{rpm}$. From the remaining incubation mixture $20 \mu \mathrm{l}$ was used to establish the exact concentration of ${ }^{3} \mathrm{H}$-labelled dexamethasone. Tubes containing protein pellets were washed three times with $1 \mathrm{ml}$ of incubation buffer (50 mM Tris-HCI pH 7.4, 1.5 mM EDTA, 1.5 mM DTT,
$10 \%$ glycerol) and pellets were solubilized in Solue ne350 (Packard, Meriden, CT). Thereafter, samples were transferred to scintillation vials and radioactivity was determined by liquid scintillation counting. Specific binding was calculated as the difference between the totally bound radioactivity and the nonspecifically bound radioactivity at each glucocorticoid concentration. Nonspecific binding was calculated from the aliquots containing the 100 -fold molar excess nonradioactive dexamethasone, assuming that nonspecific binding was nonsaturable and linearly related to the concentration of free glucocorticoid.

\section{Analysis}

Binding curves were constructed from increasing concentrations of ${ }^{3} \mathrm{H}$-dex amethasone. GR number and $\mathrm{K}_{\mathrm{d}}$ values were determined by Scatchard analysis of these data. Data were expressed as mean fmol/mg protein specific binding \pm the standard error of the mean (SEM). The Wilcoxon Matched-Pair SignedRanks test was used to assess the equality of GR number and $K_{d}$ distributions in HBEC from patients with COPD and controls. A P-value of less than 0.05 was considered significant.

\section{Results}

\section{Expression of glucocorticoid receptor protein in normal HBEC}

Cytosolic fractions were isolated from HBEC, BEAS 2B and COS-1 cells, and GR levels were examined by Western blotting. The GR polyclonal rabbit antibody
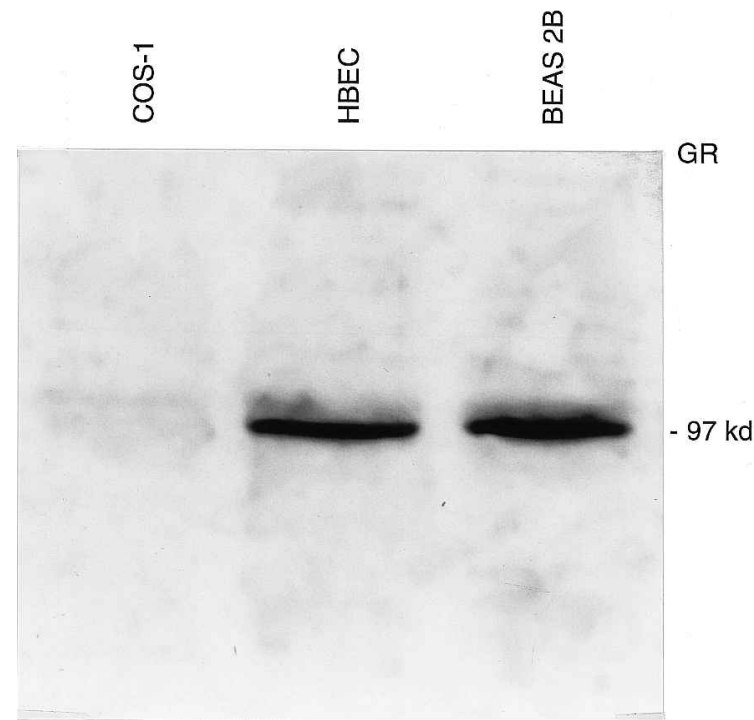

FIG. 1. Western blot of $20 \mu \mathrm{g}$ protein illustrating immunoreactive GR levels in cultured human bronchial epithelial cells (BE) and in the cell line BEAS 2B. One representative experiment out of three is shown. The COS-1 cell line $(20 \mu \mathrm{g})$ was used as a negative control. 

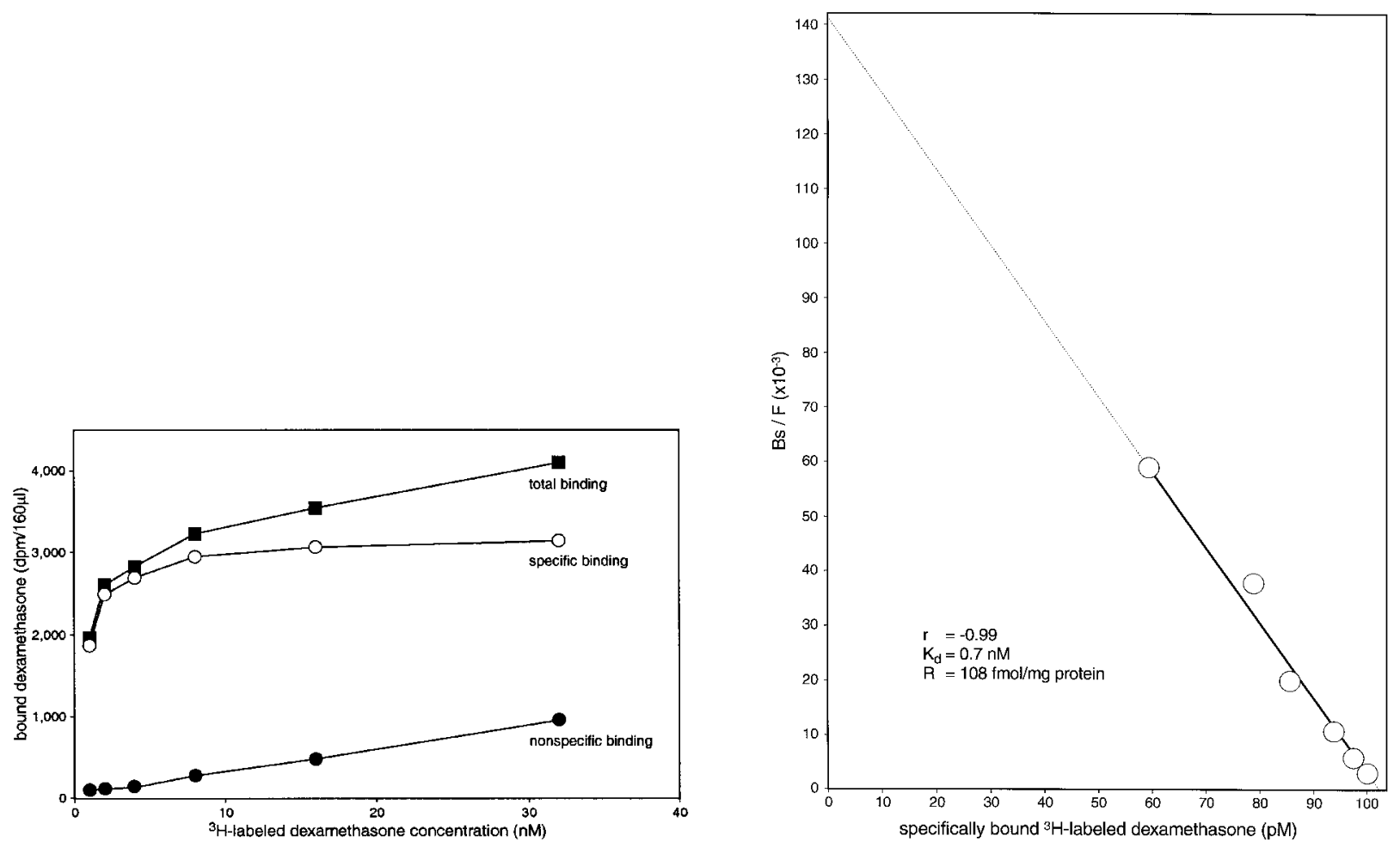

FIG. 2. (A) Binding curve of ${ }^{3} \mathrm{H}$-labelled dexametha sone for cultured HBEC. The specific binding is represented by the difference between the total and nonspecific binding. The data points represent mean values of duplicate determinations. (B) Scatchard plot of the specific binding of ${ }^{3} \mathrm{H}$-labelled dexamethasone to HBEC. On the ordinate is given the ratio of the number of specifically bound ${ }^{3} \mathrm{H}$-labelled dexamethasone (Bs) to the number of free ${ }^{3} \mathrm{H}$-labelled dexamethasone (F). One representative experiment out of 11 is shown. The $K_{d}$ and the number of glucocorticoid binding sites per mg protein (R) were calculated using the negative inverse of the slope and the $\times$ intercept, respectively.

recognized a prominent band at $-97 \mathrm{kDa}$ in the $\mathrm{HBEC}$ and BEAS 2B preparations (Fig. 1). This estimated molecular mass is consistent with that reported previously for the human GR. ${ }^{20}$ In the GR negative cell line COS-1, no immunoreactive protein was de te ctable.

After demonstrating the presence of GR protein, the number of GR and $K_{d}$ values were studied in cultured HBEC from controls $(n=11)$. Using established methods to identify GR, we could demonstrate specific binding of ${ }^{3} \mathrm{H}$-labelled dexamethasone by these cells. A typical binding curve for cultured HBEC is shown in Fig. 2A. After Scatchard analysis of the data, the linear regression line obtained indicated a single class of GR (Fig. 2B).

\section{GR binding in HBEC COPD patients, smokers and controls}

HBEC were isolated from bronchus tissue from eight COPD patients and 11 controls. The COPD and control group contained five and six smoking individuals, respectively. Cells were cultured for one passage. Thereafter, cytosols were prepared and the number of glucocorticoid binding sites and $\mathrm{K}_{\mathrm{d}}$ were determined. Results are presented in Table 2 and Fig. 3. A significant difference $w$ as found between the $K_{d}$ values in HBEC from smoking $\left(K_{d}=0.98 \pm 0.08 \mathrm{nM}\right)$ and nonsmoking controls $\left(K_{d}=0.76 \pm 0.10 \mathrm{nM}, P=\right.$ 0.03), but no significant difference was found between the mean number of binding sites (70.5 \pm

Table 2. Glucocorticoid binding in HBEC from smoking and nonsmoking COPD patients and controls

\begin{tabular}{lcccc}
\hline & $\begin{array}{c}\text { Controls } \\
\text { Nonsmoking }(n=5)\end{array}$ & $\begin{array}{c}\text { COPD patients } \\
\text { Smoking }(n=6)\end{array}$ & Nonsmoking $(n=3)$ & Smoking $(n=5)$ \\
\hline $\mathrm{R}$ (fmol/mg protein) & $87.2 \pm 16.7$ & $70.5 \pm 14.0$ & $79.7 \pm 22.6$ & $68.4 \pm 12.8$ \\
$\mathrm{~K}_{d}(\mathrm{nM})$ & $0.76 \pm 0.10$ & $0.98 \pm 0.08^{*}$ & $0.74 \pm 0.19$ & $0.71 \pm 0.15$ \\
\hline
\end{tabular}

Data are shown as mean \pm SEM. R: number of glucocorticoid binding sites; $K_{d}$ : dissociation constant. ${ }^{*}$ : significantly higher $(P<0.05)$ than in nonsmoking controls. 



FIG. 3. Total number of GR (A) and $K_{d}$ values (B) in cultures of HBEC from nonsmoking controls $(\boldsymbol{n}=5)$, smoking controls $(\boldsymbol{n}$ $=6$ ), nonsmoking COPD patients $(\boldsymbol{n}=3)$ and smoking COPD patients $(\boldsymbol{n}=5)$. Data are shown as mean \pm SEM. ${ }^{*} \boldsymbol{P}<0.05$ for smoking controls versus nonsmoking controls. sm: smoking.

14.0 and $87.2 \pm 16.7 \mathrm{fmol} / \mathrm{mg}$ protein, respectively, $P$ $=0.3)$. Furthermore, values measured in nonsmoking and smoking COPD patients $(P=0.6$ and $P=0.6$, respectively) did not differ significantly. Nor was any significant difference observed in glucocorticoid binding sites or $\mathrm{K}_{\mathrm{d}}$ between nonsmoking COPD patients and nonsmoking controls $(P=0.6$ and $P=$ 0.6 , respectively) or between smoking COPD patients and smoking controls $(P=0.9$ and $P=0.1$, respectively).

\section{Discussion}

In this study we identified and characterized specific GR in primary cultures of HBEC from COPD patients and controls. The presence of GR protein was demonstrated using Western blot analysis and ${ }^{3} \mathrm{H}$-dexamethasone binding studies. A significant decrease was found in the binding affinity of GR in HBEC from smoking controls compared with nonsmoking controls, but no significant difference was found between the mean number of specific glucocorticoid binding sites. Furthermore, values measured in nonsmoking and smoking COPD patients did not differ significantly. Nor was any difference observed between the mean number of binding sites and the $\mathrm{K}_{\mathrm{d}}$ values in $\mathrm{HBEC}$ from nonsmoking COPD patients and the values measured in nonsmoking controls or between the values measured in smoking COPD patients and smoking controls.
HBEC are considered to play an important role in airway inflammation. ${ }^{1-5}$ Inhaled glucocorticoids are used to suppress airway inflammation and, concomitantly, to improve clinical parameters. The finding that HBEC possess functional GR allows us to hypothesize that the clinical response to inhaled glucocorticoids, which mainly precipitate in the larger airways, results, at least partly, from the modulation of airway epithelial cell functions. From the $K_{d}$ value of the GR in HBEC observed in our studies, we expect that effective in vivo glucocorticoid concentrations should be around $1 \mathrm{nM}$. In a recent study by Van den Bosch et al. ${ }^{21}$ it was shown that at least $90 \mathrm{~min}$ after inhalation of $1.6 \mathrm{mg}$ budesonide, lung tissue concentrations ranged from 2.1 to $8.9 \mathrm{nM}$. Therefore, we can assume that therapeutical inhalation of glucocorticoids results in such concentrations of glucocorticoids in lung tissue that interaction with GR in HBEC will occur.

In a previous study we found that the SV $40 /$ adenovirus transformed human bronchial epithelial cell line BEAS $2 \mathrm{~B}$ contained a higher number of glucocorticoid binding sites compared with peripheral blood mononuclear cells (PBMC). ${ }^{8}$ The number and quality of GR in target cells may determine the extent of glucocorticoid responsiveness. ${ }^{22}$ HBEC were observed to contain less GR than the BEAS 2B cell line $(87.4 \pm 16.5$ and $370 \pm 14 \mathrm{fmol} / \mathrm{mg}$ protein, respectively). This difference may be caused by the SV-40/adenovirus transformation. HBEC contain a relatively high num- 
ber of GR compared with PBMC, which contain approximately $30 \mathrm{fmol} / \mathrm{mg}$ protein (unpublished results). It would be interesting to investigate whether these differences in GR number result in differences in the functional response to glucocorticoids. As both epithelial cells and PBMC are able to produce IL-1ß, the inhibition of IL- $1 ß$ production by glucocorticoids may be a useful parameter to study this issue. Few data are available on the number of GR in other epithelial cells. A human epithelial duct cell line was found to contain $83-92 \mathrm{fmol} \mathrm{GR} / \mathrm{mg}$ protein. $^{23}$

Previously, we demonstrated that the inflammatory mediators IL- $1 B$ and LPS increased the GR number and $\mathrm{K}_{\mathrm{d}}$ in BEAS $2 \mathrm{~B}$ cells. ${ }^{8}$ Similar results were found in other cell types. ${ }^{9-11}$ These results suggest that inflammatory processes may indirectly influence the response of bronchial epithelium to glucocorticoid therapy via production of cytokines by infiltrating cells. It has been suggested that in COPD, bronchial inflammation is responsible for the development of airway hyperreactivity, and chronic airflow limitation. ${ }^{12}$ Cigarette smoking causes an inflammatory reaction in the airways and can lead to the development of COPD. ${ }^{13}$ We found a significantly decreased binding affinity of the GR in smoking controls when compared with values found in nonsmoking controls. These results indicate that the inflammation present in the airways of smokers may influence the binding affinity of GR receptors. The finding that in vivo inflammation found in smokers affects GR characteristics in HBEC is in accordance with our above mentioned findings in vitro. However, we did not find any difference in the binding affinity of the GR in smoking COPD patients when compared with values in nonsmoking COPD patients. A study by Linden et al. ${ }^{13}$ showed that obstructed smoking COPD patients had significantly lower concentrations of inflammatory cells in the bronchial lavage fluid compared with nonobstructed smoking individuals. The refore, it was suggested that obstructed and nonobstructed smokers may differ in the type of airway inflammation present. The presence of lower concentrations of inflammatory cells in obstructed smoking COPD patients in the study by Linden et al. may explain why in our study no differences in GR binding affinity were found between smoking and nonsmoking obstructed COPD patients. Furthermore, we did not find any difference in the binding affinity of the GR in COPD patients when compared with values found in controls. Different inflammatory mediators may be involved in COPD and in smoking and it remains to be established which mediators actually alter GR characteristics. The actual mechanisms by which inflammatory mediators, present in the airways of smoking controls can induce a decrease in GR binding affinity in HBEC remain to be established. Others have show $n$ that altered expression of glucocorticoid-regulated proteins appears to be mediated via interaction of the modulatory domain of the GR with transcriptional factors, such as AP-1. ${ }^{24-26}$ Overexpression of AP-1 interferes $w$ ith the function of the modulatory domain of the GR. Because cytokines can induce elevated levels of AP-1, it has been suggested that this may provide a plausible explanation for the decreased ligand binding affinity of nuclear GR for glucocorticoids found in T cells after incubation with IL-2 and IL $-4 .^{24-26}$ Perhaps, a similar explanation could be given for the decreased GR binding affinity in HBEC induced by inflammatory mediators in the airways of smoking controls. Another explanation for decreased GR binding affinity could be a modulating effect of inflammatory mediators in the airways of smoking controls on the expression and phosphorylation of heat shock proteins, which are associated with the unliganded GR. ${ }^{27,28}$ Bacterial products and cytokines can regulate the expression and phosphorylation of heat shock proteins and this may modulate glucocorticoid binding to the GR. ${ }^{27,28}$ Further studies are necessary to clarify the exact mechanism of the effects of these inflammatory mediators found in the airways of smoking controls on GR.

We did not find any difference in the number of GR between COPD patients and controls, nor between smoking and nonsmoking controls. However, it cannot be excluded that differences, present between the groups in vivo, disappeared during isolation and culture of these cells. We tried to clarify this issue and tested cultures of HBEC at subsequent passages. Similar numbers of GR and $K_{d}$ values were found in subsequent passages. Others have found that increased GR numbers and decreased GR binding affinity in $\mathrm{T}$ cells from steroid resistant asthmatic patients reverted to normal after $48 \mathrm{~h}$ in culture. ${ }^{29}$ It would be interesting to study GR number and affinity directly on the bronchial tissue or directly after cell isolation. However, performance of a ${ }^{3} \mathrm{H}$-dexamethasone binding assay, the most sensitive method to determine GR number and affinity, directly after cell isolation is not possible, because of the low cell number obtained. We are currently working on a me thod to quantify GR number in small cell samples by flow cytometry using several GR specific antibodies.

To our knowledge, no other studies have been published on GR number and $\mathrm{K}_{d}$ values in HBEC from smoking and nonsmoking COPD patients and controls. Until now, most investigations have concentrated on the analysis of GR in PBMC, comparing asthmatics with healthy individuals..$^{30,31}$ No differences in GR number or GR binding affinity were found between PBMC from asthmatics and controls. $^{23,29}$ Recently, Kam et al. ${ }^{10}$ showed that PBMC from steroid resistant asthmatics had a significantly reduced GR binding affinity and an increased GR number when compared with normal subjects. Others have claimed that the clinical response to gluco- 
corticoids can not be explained by abnormal GR number or affinity. ${ }^{32}$ They suggested that the ability of GR to bind to their DNA binding sites (GRE) is impaired. Further studies are necessary to clarify whether the clinical response to inhaled glucocorticoids is related to the number and binding affinity of GR and which cells are involved in this response. As only a subgroup of COPD patients responds to inhaled glucocorticoids, it is of interest to look in resistant patients for correlations between the clinical response to glucocorticoids and the number of GR and their $K_{d}$ in bronchial epithelial cells. ${ }^{33}$

In conclusion, we demonstrated that cultured HBEC possess a single class of specific GR and that the binding affinity of GR in HBEC from smoking controls was significantly decreased when compared with values found in nonsmoking controls. These results provide further evidence that the bronchial epithelium may be an actual target for glucocorticoid therapy. Furthermore, our findings are the first indication that altered GR characteristics are present in cultured HBEC from smokers. We hypothesize that this may result from the inflammation found in the airways from smokers.

\section{References}

1. Mattoli S, Masiero M, Calabrò F, Mezzetti M, Plebani M, Allegra L. Eicosanoid release from human bronchial epithelial cells upon exposure to toluene diisocyanate in vitro. J Cell Physiol 1990; 142:379-385.

2. Salari H, Chan-Yeung M. Release of 15-hydroxyeicosatetraenoic acid (15-HETE) and prostaglandin $\mathrm{E}_{2}\left(\mathrm{PGE}_{2}\right)$ by cultured human bronchial epithelial cells. Am J Respir Cell Mol Biol 1989; 1: 245-280.

3. Marini M, Vittori E, Hollemborg J, Mattoli S. Expression of the potent inflammatory cytokines, granulocyte-macrophage-colony-stimulating factor and interleukin- 6 and interleukin-8, in bronchial epithelial cells of patients with asthma. J Allergy Clin Im munol 1992; 89: 1001-1009.

4. Vittori E, Marini M, Fasoli A. Increased expression of endothelin in bronchial epithelial cells of asthmatic patients and effects of corticosteroids. Am Rev Respir Dis 1992; 146: 1320-1325.

5. Becker S, Quay J, Koren HS, Haskill JS. Constitutive and stimulated MCP1 , GRO $\alpha, \beta$, and $\gamma$ expression in human airway epithelium and bronchoalveolar macrophages. Am J Physiol 1994; 266 (Lung Cell Mol Physiol 10): L278-L286.

6. Corrigan C. Mechanism of glucocorticoid action in asthma: too little, too late. Clin Exp Allergy 1992; 22: 315-317.

7. Sousa AR, Poston RN, Lane SJ, Nakhosteen JA, Lee TH. Detection of GM$\mathrm{CSF}$ in asthmatic bronchial epithelium and decrease by inhaled corticosteroids. Am Rev Respir Dis 1993; 147: 1557-1561.

8. Barnes PJ, Pedersen S. Efficacy and safety of inhaled corticosteroids in asthma. Am Rev Respir Dis 1993; 148: S1-S26.

9. Verheggen MM, van Hal PThW, Adriaansen-Soeting PWC, Goense BJA, Hoogsteden HC, Brinkmann AO, Versnel MA. Expression of glucocorticoid receptors in human bronchial epithelial cell lines; modulation by IL-1 $\beta$, TNF- $\alpha$ and LPS. Eur Respir J 1996; 9: 2036-2043.

10. Kam JC, Szefler SJ, Surs W, Sher ER, Leung DYM. Combination of IL-2 and IL 4 reduces glucocorticoid receptor-binding affinity and T cell response to glucocorticoids. J Im munol 1993; 151: 3460-3466.

11. Rakasz E, Gal A, Biró J, Balas G, Falus A. Modulation of glucocorticosteroid binding in human lymphoid, monocytoid and hepatoma cell lines by inflammatory cytokines interleukin (IL) $-1 \beta$, IL-6 and tumour necrosis factor (TNF)- $\alpha$. Scand J Im m unol 1993; 37: 684-689.

12. Salkowski CA, Vogel SN. INF- $\gamma$ mediates increased glucocorticoid receptor expression in murine macrophages. I Im munol 1992; 148: $2770-2777$.

13. Linden M, Rasmussen JB, Piitulainen E, et al. Airway inflammation in smokers with nonobstructive and obstructive chronic bronchitis. Am
Rev Respir Dis 1993; 148: 1226-1232.

14. American Thoracic Society. Standards for the diagnosis and care of patients with chronic obstructive pulmonary disease (COPD) and asthma. Am Rev Respir Dis 1987; 136: 225-244.

15. Verheggen MM, de Bont HI, Adriaansen-Soeting PWC, et al. Expression of lipocortins in human bronchial epithelial cells: effects of II-1ß, TNF- $\alpha$, LPS and dexamethasone. Med Inflam 1996; 5: 210-217.

16. Reddel RR, Ke Y, Gerwin BI, et al. Transformation of human bronchial epithelial cells by infection with SV40 or adenovirus-12 SV40 hybrid virus or transfection via strontium phosphate coprecipitation with a plasmid containing SV40 early region genes. Cancer Res 1988; 48: 1904-1909.

17. Berrevoets CA, Veldschlote J, Mulder E. Effects of antiandrogens on transformation and transcription activation of wild-type and mutated (LNCaP) androgen receptors. J Stero id Biochem Molec Biol 1993; 6: 731-736.

18. Bradford MM. A rapid and sensitive method for the quantification of microgram quantities of protein utilizing the principle of protein-dye binding. Annal Biochem 1976; 71: 248-254.

19. Veldscholte J, Voorhorst-Ogink MM, Bolt-de Vries J, Van Rooij HCJ, Trapman J, Mulder E. Unusual specificity of the androgen receptor in the human prostate tumor cell line LNCaP: high affinity for prostagenic and estrogenic steroids. Biochim et Biophys Acta 1990; 1052: 187-194.

20. Cidlow ski JA, Bellingham DL, Powell-Oliver FE, Lubahn DB, Sar M. Novel antipeptide antibodies to the human glucocorticoid receptor: recognition of multiple receptor forms in vitro and distinct localization of cytoplasmic and nuclear receptors. Mol Endocrinol 1990; 90: 1427-1436.

21. Van den Bosch JMM, Westermann CJJ, Aumann J, Edsbäcker S, Tönnesson $\mathrm{M}$, Selroos O. Relationship between lung tissue and blood concentrations of inhaled budesonide. Biopharm Drug Dispos 1993; 14: 455-459.

22. Homo-Delarche F. Glucocorticoid receptors and steroid sensitivity in normal and neoplasic human lymphoid tissues: a review. Cancer Res 1984; 44: 431-437

23. Kurokaw a R, Hatakeyama S, Kyakumoto S, Ota M. Cytosol glucocorticoid receptor in the neoplastic epithelial duct cell line from human salivary gland (HSG). Biochem Int 1986; 4: 671-679.

24. Yang-Yen H-F, Chambard J-C, Sun Y-I, Smeal T, Schmidt TJ, Drouin J, Karin $M$. Transcriptional interference between c-Jun and the glucocorticoid receptor: mutual inhibtion of DNA binding due to direct protein-protein interaction. Cell 1990; 62: 1205-1215.

25. Jonat C, Rahmsdorf HJ, Park K-K, et al. Antitumor promotion and antiinflammation: down-modulation of AP-1 (Fos/Jun) activity by glucocorticoid hormone. Cell 1990; 62: 1189-1204.

26. Schüle R, Rangarajan P, Kliewer $S$, et al. Functional antagonism between oncoprotein c-Jun and the glucocorticoid receptor. Cell 1990; 62 1217-1226.

27. Fincato G, Polentarutti N, Sica A, Mantovani A, Colotta F. Expression of a heat-inducible gene of the HSP70 family in human myelomonocytic cells: regulation by bacterial products and cytokines. Blood 1991; 77: $579-586$.

28. Satoh J, Kim SU. Cytokines and grow th factors induce HSP27 phosphorylation in human astrocytes. I Neuropathol Exp Neurol 1995; 54: 504-512.

29. Sher ER, Leung DYM, Surs W, et al. Steroid-resistant asthma. Cellular mechanisms contributing to inadequate response to glucocorticoid therapy. J Clin Invest 1994; 93: 33-39.

30. Tsai BS, Watt G, Koesnadi K, Tow nley RG. Lymphocyte glucocorticoid receptors in asthmatic and control subjects. Clin Allergy 1984; 14: $363-371$.

31. Lane SJ, Lee TH. Glucocorticoid receptor characteristics in monocytes of patients w ith corticosteroid-resistant bronchial asthma. Am Rev Respir Dis 1991; 143: 1020-1024.

32. Adcock LM, Lane SJ, Brown CR, Peters MJ, Lee TH, Barnes PJ. Differences in binding of glucocorticoid receptor to DNA in steroid-resistant asthma. J Im m unol 1995; 154: 3500-3505.

33. Callahan C, Dittus RS, Katz BP. Oral corticosteroid the rapy for patients with stable chronic obstructive pulmonary disease: a meta-analysis. Ann Intern Med 1991; 114: 216-223.

ACKNOWLEDGEMENTS. We gratefully acknowledge the continuous support of Professor Dr R. Benner. Dr J. Lechner kindly provided the BEAS 2B cell line. We thank Mr T. M. van Os for excellent photographic assistance and Ms P. C. Assems for secretarial assistance. This study was supported by the Netherlands Asthma Foundation (90.44).

\section{Received 20 April 1998; accepted 29 April 1998}




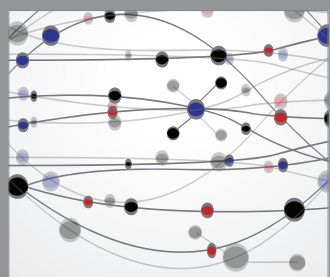

The Scientific World Journal
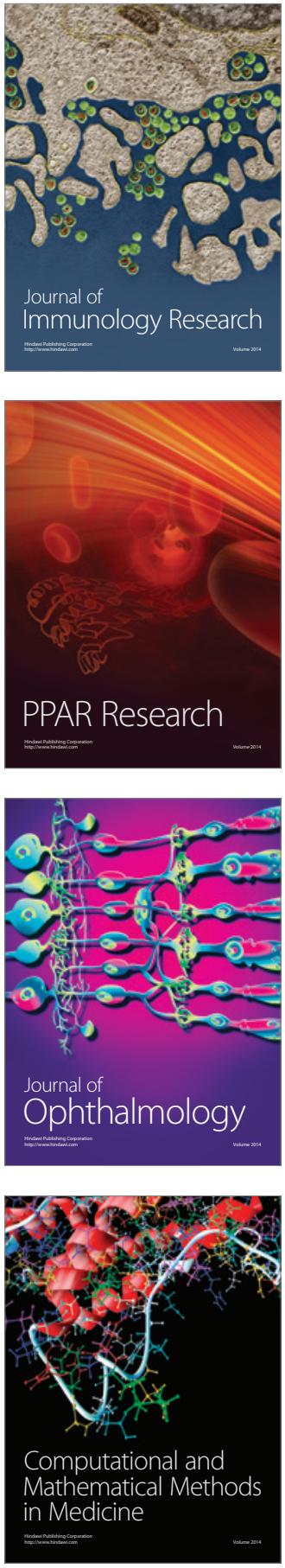

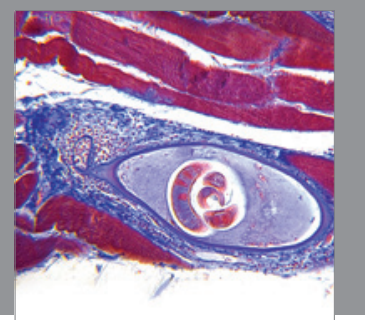

Gastroenterology

Research and Practice
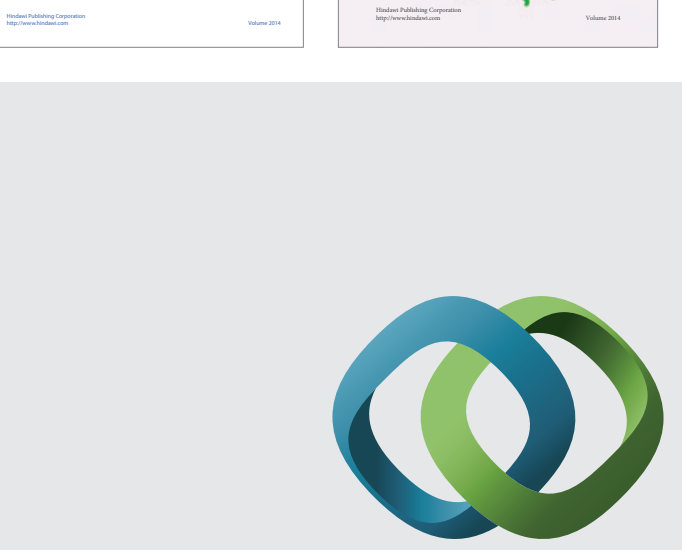

\section{Hindawi}

Submit your manuscripts at

http://www.hindawi.com
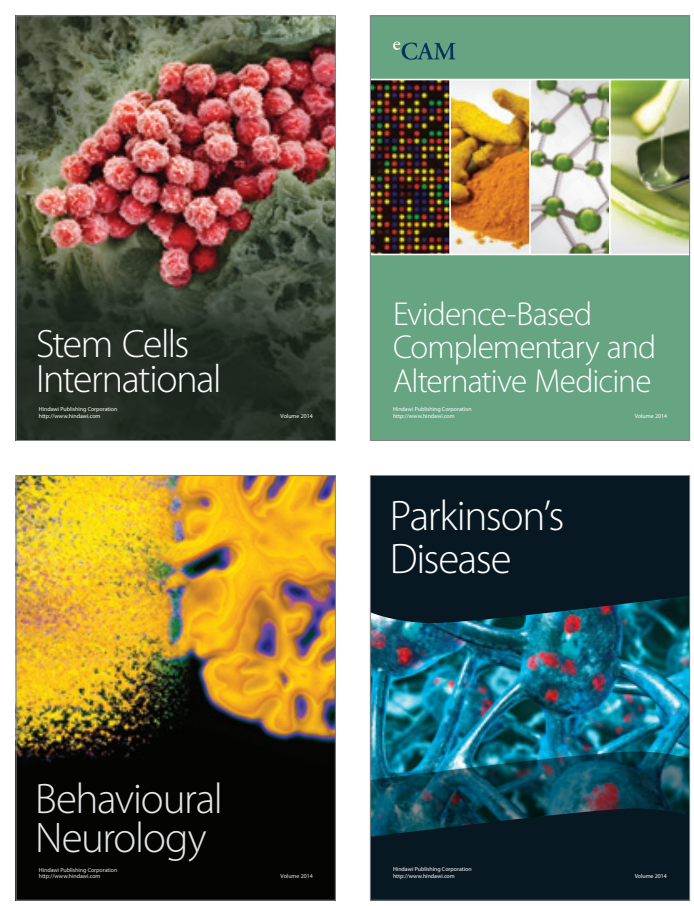

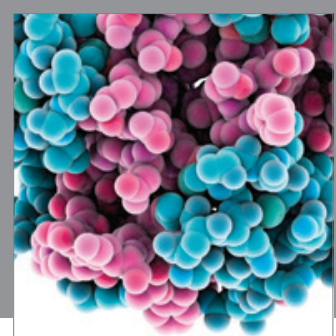

Journal of
Diabetes Research

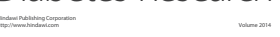

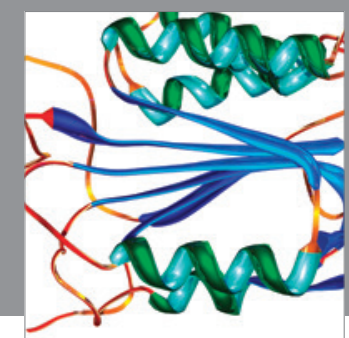

Disease Markers
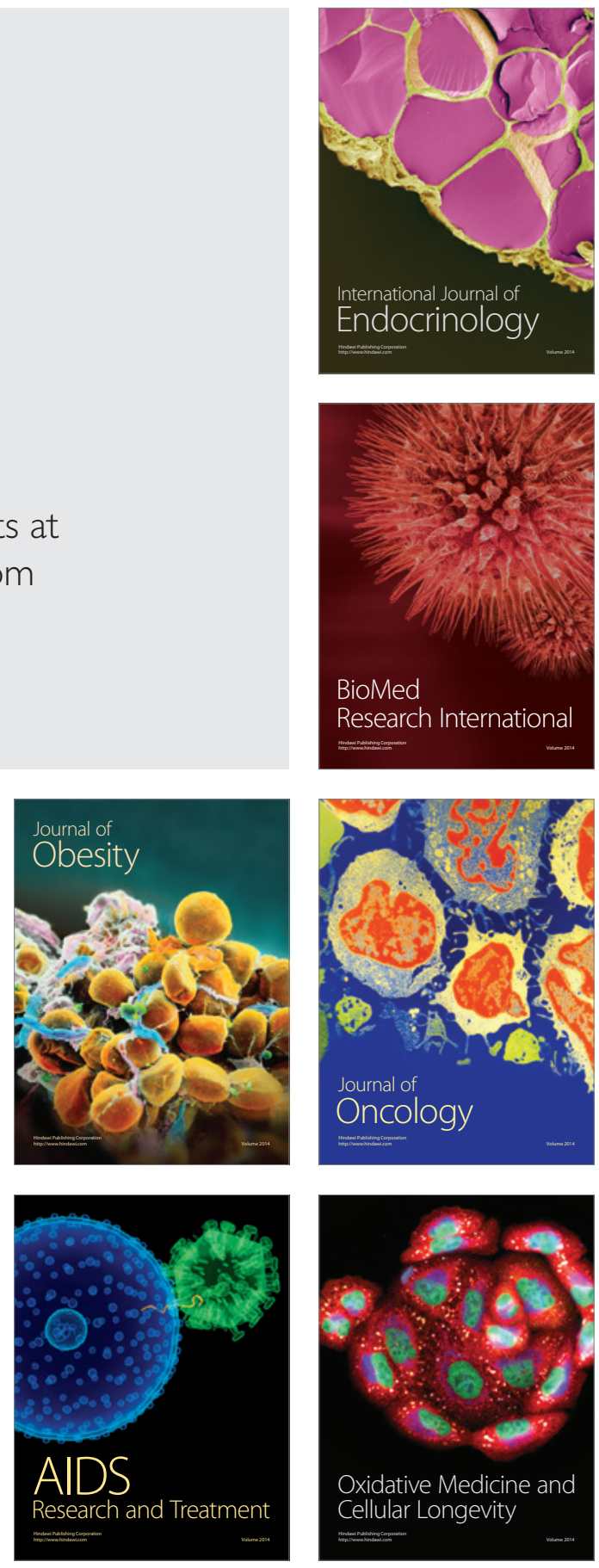